\title{
The WNK-SPAK/OSR1 Kinases and the Cation-Chloride Cotransporters as Therapeutic Targets for Neurological Diseases
}

\author{
Huachen Huang 1, 2, Shanshan Song ${ }^{2}$, Suneel Banerjee², Tong Jiang ${ }^{2}$, Jinwei Zhang ${ }^{3}$, Kristopher \\ T. Kahle ${ }^{4}$, Dandan Sun ${ }^{2,5^{*}}$, Zhongling Zhang ${ }^{*}$ \\ ${ }^{1}$ Department of Neurology, The First Affiliate Hospital, Harbin Medical University, Harbin, Heilongjiang, China. \\ ${ }^{2}$ Department of Neurology, University of Pittsburgh, Pittsburgh, PA, USA. ${ }^{3}$ Institute of Biomedical and Clinical \\ Sciences, University of Exeter Medical School, Hatherly Laboratory, Exeter, EX4 4PS, UK. ${ }^{4}$ Departments of \\ Neurosurgery, Pediatrics, and Cellular \& Molecular Physiology, Centers for Mendelian Genomics, Yale School of \\ Medicine, New Haven, CT, USA. ${ }^{5}$ Veterans Affairs Pittsburgh Health Care System, Geriatric Research, Education \\ and Clinical Center, Pittsburgh, PA, USA.
}

[Received August 19, 2018; Revised September 27, 2018; Accepted September 28, 2018]

\begin{abstract}
In recent years, cation-chloride cotransporters (CCCs) have drawn attention in the medical neuroscience research. CCCs include the family of $\mathrm{Na}^{+}$-coupled $\mathrm{Cl}^{-}$importers (NCC, NKCC1, and NKCC2), $\mathrm{K}^{+}$coupled $\mathrm{Cl}^{-}$exporters (KCCs), and possibly polyamine transporters (CCC9) and $\mathrm{CCC}$ interacting protein (CIP1). For decades, CCCs have been the targets of several commonly used diuretic drugs, including hydrochlorothiazide, furosemide, and bumetanide. Genetic mutations of NCC and NKCC2 cause congenital renal tubular disorders and lead to renal salt-losing hypotension, secondary hyperreninemia, and hypokalemic metabolic alkalosis. New studies reveal that CCCs along with their regulatory WNK (Kinase with no lysine (K)), and SPAK (Ste20-related proline-alanine-rich kinase)/ OSR1(oxidative stress-responsive kinase-1) are essential for regulating cell volume and maintaining ionic homeostasis in the nervous system, especially roles of the WNKSPAK-NKCC1 signaling pathway in ischemic brain injury and hypersecretion of cerebrospinal fluid in posthemorrhagic hydrocephalus. In addition, disruption of $\mathrm{Cl}^{-}$exporter $\mathrm{KCC} 2$ has an effect on synaptic inhibition, which may be involved in developing pain, epilepsy, and possibly some neuropsychiatric disorders. Interference with KCC3 leads to peripheral nervous system neuropathy as well as axon and nerve fiber swelling and psychosis. The WNK-SPAK/OSR1-CCCs complex emerges as therapeutic targets for multiple neurological diseases. This review will highlight these new findings.
\end{abstract}

Key words: brain edema, cell volume regulation, ischemic stroke, KCCs, NKCC1, WNK-SPAK/OSR1

Maintaining intracellular ionic homeostasis is essential for physiological function in all cells. A family of electroneutral transporters, the SLC12A family of CCCs (cation-chloride cotransporters), and their upstream regulatory serine-threonine kinases, the WNK (Kinase with no lysine (K)), SPAK (Ste20-related proline-alaninerich kinase) as well as OSR1 (oxidative stress-responsive kinase-1), play integral roles in the regulation of intracellular $\mathrm{Na}^{+}, \mathrm{K}^{+}$, and $\mathrm{Cl}^{-}$homeostasis as well as cell volume homeostasis [1-3]. The CCC family is comprised

*Correspondence should be addressed to: Dr. Dandan Sun, Department of Neurology, University of Pittsburgh, Pittsburgh, USA. Email: sund@upmc.edu. Dr. Zhongling Zhang, The First Affiliated Hospital, Harbin Medical University, China. Email: zhangzhongling@outlook.com

Copyright: $\odot 2018$ Huang $\mathrm{H}$ et al. This is an open-access article distributed under the terms of the Creative Commons Attribution License, which permits unrestricted use, distribution, and reproduction in any medium, provided the original author and source are credited. 
of the $\mathrm{Na}^{+}, \mathrm{K}^{+}$-coupled $\mathrm{Cl}^{-}$importers ( $\mathrm{NCC}, \mathrm{NKCC1}$, and $\mathrm{NKCC} 2)$ and the $\mathrm{K}^{+}$-coupled $\mathrm{Cl}^{-}$exporters (KCC1-4) [4, 5]. Isoforms of WNK are phosphorylated (activated) in response to osmotic stress or when intracellular $\mathrm{Cl}^{-}$levels are low, and subsequently phosphorylate the related downstream kinases SPAK and/or OSR1 [6, 7]. Activated SPAK and/or OSR1 in turn stimulates NCC, NKCC1, NKCC2 via protein phosphorylation, but inhibits KCCs (with phosphorylation), via a reciprocal regulatory mechanism [8]. The inverse regulation of these ion cotransporters is driven by the same kinase-phosphatase signaling pathway to coordinate cellular $\mathrm{Cl}^{-}$efflux and influx in the cells to maintain $\mathrm{Cl}^{-}$homeostasis and avoid unnecessary ATP consumption. Generally, NKCC1, NKCC2, and NCC mediate $\mathrm{Na}^{+}, \mathrm{K}^{+}$, and $\mathrm{Cl}^{-}$influx, while $\mathrm{KCC} 1-4$ mediate $\mathrm{K}^{+}$and $\mathrm{Cl}^{-}$efflux [9]. Abnormal function of the SLC12A family members was first associated with kidney dysfunction and diseases. Mutations of these CCCs can cause congenital renal tubular disorders such as renal salt-wasting syndromes [Gitelman syndrome (GS) and Bartter syndrome (BS)], and lead to secondary hyperaldosteronism and hypokalemic metabolic alkalosis (Table 1). Both GS and BS are caused by autosomal recessive gene mutations of NCC in the distal convoluted tubules (DCT) and NKCC2 in the thick ascending limb (TAL) of the loop of Henle (Table 1) [10]. BS is divided into 5 types, each with different causes. Type I BS is caused by a forementioned SLC12A mutation (NKCC2) [11]. Other causes of BS include mutations in the potassium voltage-gated channel subfamily J member 1 (KCNJ1) for Type II BS, chloride channel $\mathrm{Kb}(\mathrm{ClC}-\mathrm{Kb})$ for Type III BS, Bartter syndrome, infantile, with sensorineural deafness (BSND) for Type IV $\mathrm{BS}$, and calcium-sensing receptor (CaSR) for Type V BS [11]. All of these disorders are caused by the disruption of ion homeostasis $[12,13]$. New studies suggest that the WNK-SPAK/OSR1-CCC pathway is also involved in neurological diseases such as ischemic stroke and neuropathy [14-19]. This review will give readers an update on the emerging roles of WNK-SPAK/OSR1-CCC signaling pathway in neurological diseases.

\section{WNK-SPAK/OSR1 kinase complex and $\mathrm{Cl}^{-}$ cotransporters in cell volume regulation in the nervous system}

Changes of intracellular osmolarity under normal physiological extracellular osmotic pressure (isosmotic stress) or anisosmotic volume stress (under hypertonic /hypotonic extracellular osmolality conditions) can trigger cellular responses in vertebrate cells to regulate volume $[20,21]$. In hypotonic extracellular conditions, water enters into cells and causes cell swelling, which triggers regulatory volume decrease (RVD), a homeostatic counter-response [22]. RVD results from the efflux of $\mathrm{K}^{+}$ and $\mathrm{Cl}^{-}$via $\mathrm{KCCs}$ (KCC1, $\mathrm{KCC} 3$, and $\mathrm{KCC} 4$ ), and/or via $\mathrm{K}^{+}$and $\mathrm{Cl}^{-}$channels along with water. The canonical volume-regulated $\mathrm{KCCs}$ are for the most part inactive under isotonic conditions but activate in response to cell swelling $[13,14]$. On the contrary, cell shrinkage due to hypertonic conditions elicits regulatory volume increase (RVI) [20], which results in $\mathrm{Na}^{+}$and $\mathrm{Cl}^{-}$influx via $\mathrm{Na}^{+}$ channels, activation of $\mathrm{NKCC} 1$, or $\mathrm{Na}^{+} / \mathrm{H}^{+}$exchange. Activation of $\mathrm{NKCC} 1$ and/or reduction of $\mathrm{KCC}$ function can cause an increase in intracellular $\mathrm{Na}^{+}$and $\mathrm{Cl}^{-}$levels, which can result in isosmotic cell swelling [23]. Cell swelling due to either isosmotic and anisosmotic conditions could contribute to swelling in neurons, glia, and capillary endothelial cells of the blood-brain barrier (BBB), which can collectively contribute to brain edema and will be discussed further [24].

The WNKs are a serine/threonine kinase family encoded by the genes WNK1-4 [25]. In the context of volume regulation, protein phosphorylation effectuated by the WNK-SPAK kinase pathway activates NKCC1 but simultaneously inhibits KCCs, whereas protein dephosphorylation inhibits NKCC1 and activates the KCCs [26]. The major phosphoregulatory sites have been identified at the N-terminus of NKCC1 at $\mathrm{Thr}^{203}, \mathrm{Thr}^{207}$ and $\mathrm{Thr}^{212}$, and in the C-terminus of KCC1-4 at $\mathrm{Thr}^{991}$ in $\mathrm{KCC} 3$ and at $\mathrm{Thr}^{906}$ in $\mathrm{KCC} 2$ in human, sharks and mice $[4,8]$. Sites homologous to KCC3 $\mathrm{Thr}^{991}$ and $\mathrm{Thr}^{1048}$ residues, Site-1 (Thr $\left.{ }^{991}\right)$ and Site- $2\left(\mathrm{Thr}^{1048}\right)$, are phosphorylated in all human KCCs [8]. Substitution of these Thr residues (with Ala) causes $\mathrm{KCC} 2$ and $\mathrm{KCC} 3$ activation due to inhibition of phosphorylation [27, 28]. Recently, a functional kinomics study showed the WNK3SPAK complex to be vital for regulating phosphorylation of KCC3 at Site-1 and Site-2 [26].

SPAK/OSR1 interacts with KCC1-4 and NKCC1 by means of a specific conserved carboxyl-terminal (CCT) domain $[26,29,30]$. SPAK's CCT domain is recognized by the Arg-The-Xaa-Val/Ile (RFXV/I) domain in the amino-terminal of KCC1-4 and NKCC1-2. KCC2 subtype $\mathrm{KCC} 2 \mathrm{~b}$ has no RFXV/I motif, so SPAK overexpression decreases the transport activity of KCC2a but not KCC2b [5, 31]. This ability of SPAK/OSR1 (via CCT) to attach to both the WNKs and CCCs (upstream and downstream) is essential for coordinating cellular cotransporter activity in isosmotic or hyperosmotic conditions [30, 32]. WNK's binding to SPAK/OSR1 allows the phosphorylation of residues found in the T-loop of the SPAK catalytic domain $[30,32]$. This process is crucial for SPAK's ability to phosphorylate (inhibit) $\mathrm{Thr}^{991 /} \mathrm{Thr}^{1048}$ in KCC3 and $\mathrm{Thr}^{906}$ in KCC2 while phosphorylating (activating) NKCC1 at $\mathrm{Thr}^{203} / \mathrm{Thr}^{207} / \mathrm{Thr}^{212}$ in response to cellular shrinkage and hypertonicity (Fig. 1) [5]. NKCC1's phosphorylation and 
activation by SPAK/OSR1 in hypertonic conditions is a vital component of RVI $[5,33]$, which leads to influx of $\mathrm{Na}^{+}, \mathrm{K}^{+}$and $\mathrm{Cl}^{-}$along with water to achieve cell volume recovery (Fig. 1). Under hypotonic extracellular conditions, water enters the cells and causes cell swelling, subsequently triggering a counter volume regulation response, i.e., RVD. In this condition, the WNKSPAK/OSR1 pathway remains inactive and inhibits NKCC1 activity (Fig. 1). Phosphatase-mediated dephosphorylation of KCCs stimulates their activity and leads to efflux of $\mathrm{K}^{+}$and $\mathrm{Cl}^{-}$along with water, and thus decreases cell volume (Fig. 1). Therefore, pharmacological or genetic antagonism of WNKSPAK/OSR1 enables cellular chloride expulsion by simultaneously decreasing phosphorylation of NKCC1 and the KCCs, and thus acute cell swelling caused by osmotic stress may be prevented or the cerebral edema caused by energy failure diseases may be mitigated [26, $34,35]$.

Table 1. Phenotypes of transgenic knockout (KO) mice involving WNK-SPAK/OSR1-CCC complex

\begin{tabular}{|c|c|c|c|c|c|}
\hline Protein & $\begin{array}{l}\text { Co-transport } \\
\text { ions }\end{array}$ & $\begin{array}{l}\text { Tissue and Subcellular } \\
\text { Distribution }\end{array}$ & $\begin{array}{l}\text { Relating to } \\
\text { human diseases }\end{array}$ & Phenotypes of KO/KI mice & Refs. \\
\hline $\begin{array}{l}\text { SLC12A1 } \\
(\mathrm{NKCC} 2)\end{array}$ & $\mathrm{Na}^{+}, \mathrm{K}^{+}, \mathrm{Cl}^{-}$ & $\begin{array}{l}\text { Kidney-specific (TAL); } \\
\text { apical plasma membrane; } \\
\text { hypothalamo- } \\
\text { neurohypophyseal system }\end{array}$ & Bartter syndrome & $\begin{array}{l}\text { Severe hypotension, hypokalemia, } \\
\text { hypercalciuria, metabolic alkalosis }\end{array}$ & [80-82] \\
\hline $\begin{array}{l}\text { SLC12A2 } \\
(\mathrm{NKCC} 1)\end{array}$ & $\mathrm{Na}^{+}, \mathrm{K}^{+}, \mathrm{Cl}^{-}$ & $\begin{array}{l}\text { Ubiquitous; } \\
\text { basolateral plasma } \\
\text { membrane }\end{array}$ & None & $\begin{array}{l}\text { Sensorineural deafness, } \\
\text { alterations in endolymph secretion, } \\
\text { reduced saliva production, } \\
\text { sensory perception abnormalities and infertility }\end{array}$ & $\begin{array}{l}{[58,83-} \\
86]\end{array}$ \\
\hline $\begin{array}{l}\text { SLC12A3 } \\
\text { (NCC) }\end{array}$ & $\mathrm{Na}^{+}, \mathrm{Cl}^{-}$ & $\begin{array}{l}\text { Kidney-specific (DCT); } \\
\text { bone? } \\
\text { apical plasma membrane }\end{array}$ & $\begin{array}{l}\text { Gitelman } \\
\text { syndrome }\end{array}$ & $\begin{array}{l}\text { Hypotension, hypocalciuria, hypomagnesemia, } \\
\text { hypokalemia }\end{array}$ & {$[87-89]$} \\
\hline $\begin{array}{l}\text { SLC12A4 } \\
(\mathrm{KCC} 1)\end{array}$ & $\mathrm{K}^{+}, \mathrm{Cl}^{-}$ & Ubiquitous & None & No phenotype & [90] \\
\hline $\begin{array}{l}\text { SLC12A5 } \\
(\mathrm{KCC} 2)\end{array}$ & $\mathrm{K}^{+}, \mathrm{Cl}^{-}$ & $\begin{array}{l}\text { Neuron-specific; } \\
\text { basolateral plasma } \\
\text { membrane (?) }\end{array}$ & Epilepsy & $\begin{array}{l}\text { Complete - death due to absent respiratory } \\
\text { drive. } \\
\text { Incomplete KO ( } 5 \% \text { of function remains). } \\
\text { Status epilepticus, } \\
\text { death } \pm 15 \text { days after birth. }\end{array}$ & {$[91,92]$} \\
\hline $\begin{array}{l}\text { SLC12A6 } \\
(\mathrm{KCC} 3)\end{array}$ & $\mathrm{K}^{+}, \mathrm{Cl}^{-}$ & Widespread & $\begin{array}{l}\text { Andermann } \\
\text { syndrome }\end{array}$ & $\begin{array}{l}\text { Knockout mice recapitulate the } \\
\text { locomotion and neuropathy phenotypes } \\
\text { and demonstrate axonal swelling }\end{array}$ & {$[92,93]$} \\
\hline $\begin{array}{l}\text { SLC12A7 } \\
(\mathrm{KCC} 4)\end{array}$ & $\mathrm{K}^{+}, \mathrm{Cl}^{-}$ & $\begin{array}{l}\text { Widespread; } \\
\text { basolateral plasma } \\
\text { membrane (?) }\end{array}$ & None & $\begin{array}{l}\text { Sensorineural deafness } \\
\text { and renal tubular acidosis }\end{array}$ & {$[94,95]$} \\
\hline SPAK & -- & Ubiquitous & $\begin{array}{l}\text { No report in } \\
\text { human, but } \\
\text { resemble Gitelman } \\
\text { syndrome in mice }\end{array}$ & $\begin{array}{l}\text { KO mice exhibited hypotension and } \\
\text { recapitulated Gitelman syndrome with } \\
\text { hypokalemia, hypomagnesemia, and } \\
\text { hypocalciuria; higher nociceptive threshold and } \\
\text { increased anxiety }\end{array}$ & {$[12,66]$} \\
\hline OSR1 & -- & Ubiquitous & $\begin{array}{l}\text { No report in } \\
\text { human, but } \\
\text { resemble Bartter } \\
\text { syndrome in mice }\end{array}$ & $\begin{array}{l}\text { Global } \mathrm{KO} \text { - die in utero. Heterozygous } \mathrm{KO}- \\
\text { low BP. Kidney tubule-specific } \mathrm{KO} \text { - normal } \\
\mathrm{BP} \text { with hypercalciuria and hypokalemia }\end{array}$ & {$[96,97]$} \\
\hline WNK1 & -- & Ubiquitous & $\begin{array}{l}\text { HSANII; } \\
\text { PHAII }\end{array}$ & $\begin{array}{l}\text { Less susceptible to hypersensitivity to cold and } \\
\text { mechanical stimuli after peripheral nerve injury }\end{array}$ & $\begin{array}{l}{[73,75} \\
96,98 \\
99]\end{array}$ \\
\hline WNK2 & -- & $\begin{array}{l}\text { Prominently expressed in } \\
\text { brain neurons; fetal brain } \\
\text { and heart }\end{array}$ & No report & No report & $\begin{array}{l}{[100,} \\
101]\end{array}$ \\
\hline WNK3 & -- & Ubiquitous & Autistic disorder? & $\begin{array}{l}\text { Mice exhibited less cytotoxic edema after } \\
\text { MCAO; compensated elevation of } \\
\text { WNK1/SPAK axis in the kidney }\end{array}$ & $\begin{array}{l}{[34,65} \\
72,102]\end{array}$ \\
\hline WNK4 & -- & Ubiquitous & PHAII & $\begin{array}{l}\text { KO mice exhibited hypokalemia but } \\
\text { normalcalciuria }\end{array}$ & {$[99,103]$} \\
\hline
\end{tabular}



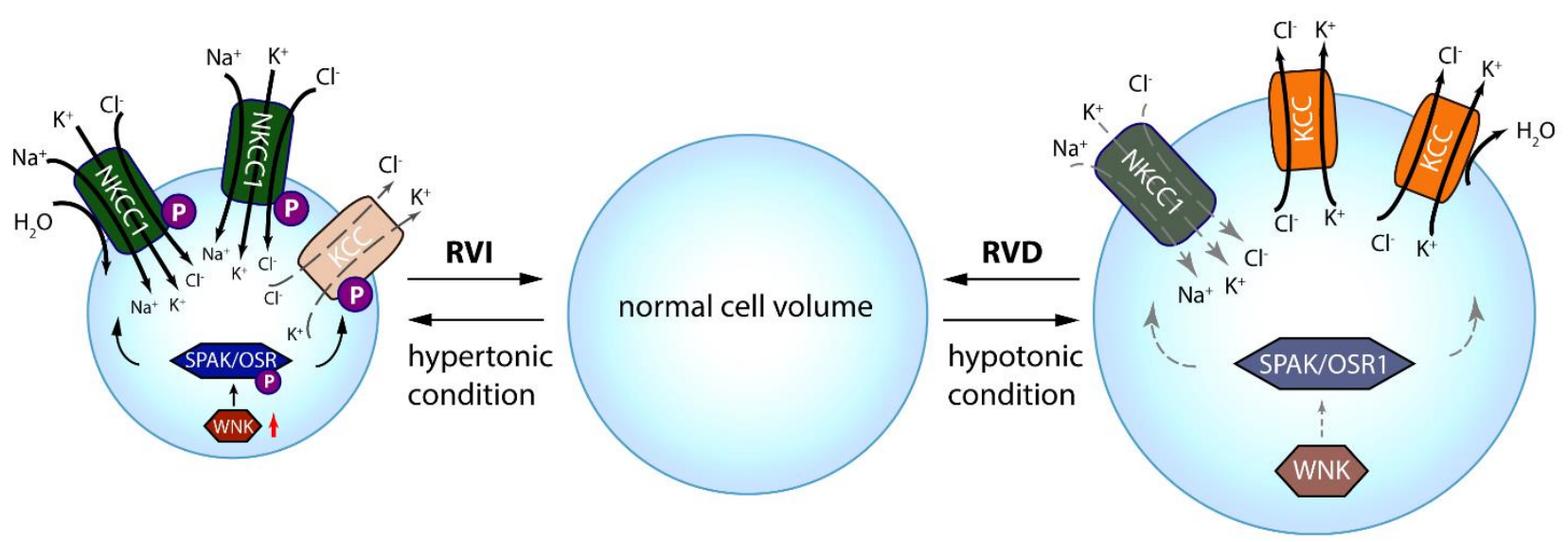

Figure 1. Roles of CCC in cell volume regulation. Intracellular osmolarity changes trigger cellular responses for volume regulation. Under hypertonic extracellular conditions, water extrudes from the cells and causes cell shrinkage, triggering a counter-response of regulatory volume increase (RVI). In this condition, the WNK-SPAK/OSR1 pathway is activated and phosphorylates NKCC1 and KCCs, resulting in NKCClactivation and KCCs inhibition. This subsequently leads to influx of $\mathrm{Na}^{+}, \mathrm{K}^{+}$and $\mathrm{Cl}^{-}$via $\mathrm{NKCC1}$ along with water, thus restoring cell volume. On the contrary, cell swelling due to hypotonic stress elicits regulatory volume decrease (RVD), in which the WNK-SPAK/OSR1 pathway remains inactive and NKCC1 and KCCs are dephosphorylated. This results in NKCC1 inhibition but stimulation of KCCs, which lead to KCC-mediated efflux of $\mathrm{K}^{+}$and $\mathrm{Cl}^{-}$along with water, and cell volume decrease.

\section{Activation of WNK-SPAK /OSR1 kinase complex by low intracellular $\mathrm{Cl}^{-}$}

The WNK kinases are not only effector kinases that work in conjunction with the SPAK/OSR1 kinases to regulate CCCs by phosphorylation, but may also serve as the intracellular $\mathrm{Cl}^{-}$sensors (potentially cell volume sensors) [6]. $\mathrm{Cl}^{-}$is a vital ion which is involved in the regulation of neuronal excitability and cell volume $[20,36] . \mathrm{Cl}^{-}$ stabilizes WNK1 in its inactive conformation and prevents kinase autophosphorylation by binding to WNK1's catalytic site, which is situated at the DLG motif and the N-terminus of the activation loop [6]. Because WNK1 is sensitive to $\mathrm{Cl}^{-}$-mediated inhibition of autophosphorylation, it effectively serves as a $\mathrm{Cl}^{-}$ concentration sensor [6]. Among WNK1-4, $\mathrm{Cl}^{-}$inhibits WNK4 kinase activity at lower concentrations than it inhibits activity of WNK1 or WNK3 [37]. In light of expression of WNK4 in the BBB endothelium and increased level in ischemic stroke of hypertensive rats [16], future studies are needed to elucidate roles of WNK4 in the CNS, especially considering to its high sensitivity to $[\mathrm{Cl}]_{\mathrm{i}}$. Developing inducible and cell-type specific WNK4 KO mice will be helpful to investigate these questions.

Furthermore, the functions of SPAK and/or OSR1 are also sensitive to the changes in $\mathrm{Cl}^{-}$concentration [38]. In the adult central nervous system (CNS), GABA is one of the main inhibitory neurotransmitters, utilizing the activated ligand-gated, $\mathrm{Cl}^{-}$-permeable $\mathrm{GABA}_{\mathrm{A}}$ receptors
$\left(\mathrm{GABA}_{\mathrm{A}} \mathrm{Rs}\right)$ to propagate its fast synaptic hyperpolarizing effect [39]. When GABA binds to and activates the $\mathrm{GABA}_{\mathrm{A}}$ receptor, the $\mathrm{Cl}^{-}$ions flow into the cell through the channel, resulting in hyperpolarization of the cell and suppression of the electrophysiological activity of the related neurons [39]. As opposed to NKCC1, increased $\mathrm{KCC} 2$ expression during brain maturation mediates $\mathrm{Cl}^{-}$ extrusion and reduces $\left[\mathrm{Cl}^{-}\right]_{\mathrm{i}}$ in neurons, which in turn favors $\mathrm{GABA}_{A} \mathrm{R}$-mediated hyperpolarization in the mature CNS [40]. The low $\left[\mathrm{Cl}^{-}\right]_{\mathrm{i}}$ maintained by $\mathrm{KCC} 2$ is required for GABA-mediated synaptic inhibition [41, 42]. However, in developing neurons, responses actuated by $\mathrm{GABA}_{\mathrm{A}} \mathrm{Rs}$ are depolarizing and sometimes excitatory, which are critical for synaptogenesis, neuronal proliferation, and migration $[43,44]$. For example, there is a "excitatory-inhibitory developmental sequence" of GABA in the nervous system, which is closely related with the $\left[\mathrm{Cl}^{-}\right]_{\mathrm{i}}[45-52]$. Increase in expression and activity of WNK3 and OSR1 was believed to be the cause of disturbance of GABA-mediated neurotransmission in CNS and consequently schizophrenia [44, 46]. Neuropathic pain and spasticity resulting from spinal cord injury (SCI) are often associated with defective GABAergic function, mainly caused by impairment of KCC2 functionality $[49,53]$. All these studies signal for importance of $\left[\mathrm{Cl}^{-}\right]_{\mathrm{i}}$ in regulating WNK. In the peripheral nervous system (PNS), glia and neurons have a relatively higher $\left[\mathrm{Cl}^{-}\right]_{\mathrm{i}}$ due to $\mathrm{KCC} 3$ 's inhibition, elevated expression of NKCC1, and an absence of KCC2 [54, 55]. In response to this higher $\left[\mathrm{Cl}^{-}\right]_{\mathrm{i}}$, WNK can be deactivated 
and lead to dephosphorylation of NKCC1 and $\mathrm{KCC} 3$, resulting in decreased NKCC1 expression and increased $\mathrm{KCC} 3$ expression and activation, which in turn reduce $\left[\mathrm{Cl}^{-}\right]_{\mathrm{i}}$ and favors GABA-mediated hyperpolarization. Thus, neurons and glia of the PNS are more efficient in volume regulation and GABAergic circuit functions due to $\mathrm{KCC} 3$-mediated $\mathrm{K}^{+}$and $\mathrm{Cl}^{-}$efflux and high-water permeability [56, 57]. Taken together, WNK-SPAK/ OSR1-mediated phosphoregulation of $\mathrm{NKCC} 1 / \mathrm{KCCs}$ might be important for determining the molecular mechanisms in diseases characterized by neuronal hyperexcitability, such as stroke and epilepsy, where lack of GABA-mediated inhibition might be responsible for the excitatory effects.

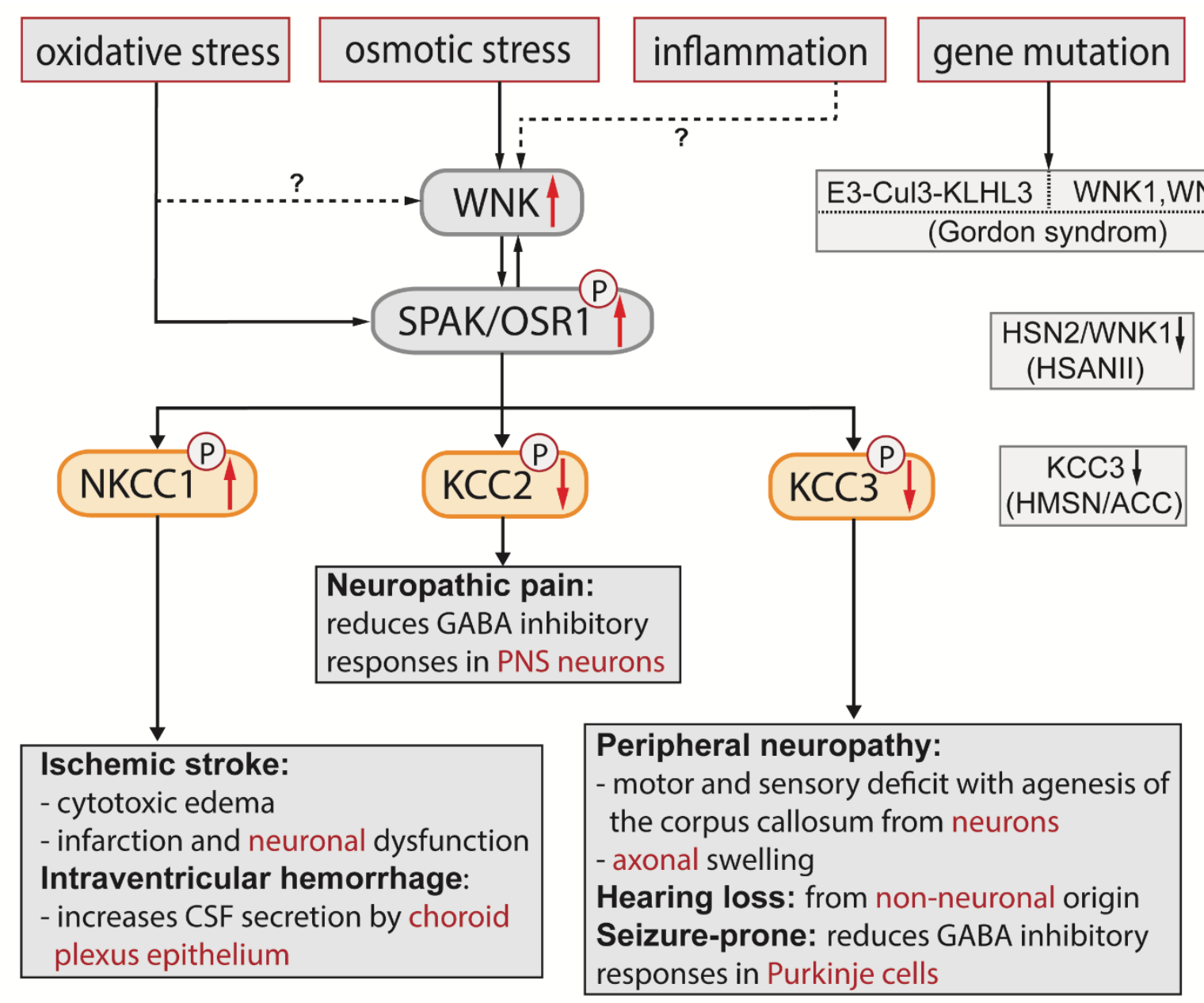

Figure 2. Illustration of the WNK-SPAK/OSR1-CCCs cascade in nervous and non-nervous system diseases. Mutations of E3 ubiquitin ligase components cullin 3 (CUL3) and kelch-like 3 (KLHL3) were identified to cause Pseudohypoaldosteronism type II (PHAII) with increased WNK1 and WNK4 abundance in kidney. Gene mutations in WNK1 and WNK4 also cause PHAII with compromised cell volume homeostasis. In addition, osmotic stress can trigger WNK-SPAK/OSR1 complex activation, which leads to downstream phosphorylation of CCCs, especially stimulatory phosphorylation of NKCC1 and inhibitory phosphorylation of KCCs. Overstimulation of NKCC1 increases cytotoxic edema, enlarges infarction, and worsens neurobehavioral function in ischemic stroke. Hyperactive NKCC1 increases CSF secretion by the choroid plexus epithelium and causes post-hemorrhagic hydrocephalus after intraventricular hemorrhage. On the other hand, phosphorylation of KCC2 by WNK-SPAK/OSR1 decreases its $\mathrm{Cl}^{-}$efflux and reduces GABA-mediated inhibition of spinal nerve transmission and causes neuropathic pain. To date, no direct evidence links oxidative stress or inflammation to WNK activation in the nervous system. However, oxidative stress can directly activate SPAK/OSR1, which in turn regulates WNK activity, thus indirectly activates WNK; inflammation-induced stimulation of the WNK-SPAK/OSR1 pathway could also increase WNK activity. Dysfunction of KCC3, such as via KCC3 mutation, leads to compromised cell volume homeostasis and causes hereditary motor and sensory neuropathy with agenesis of the corpus callosum (HMSN/ACC), hearing loss and a reduced threshold for seizure. Hereditary sensory and autonomic neuropathy type II (HSANII) caused by HSN2 gene mutations leads to a loss-of-function for WNK1 activity. Taken together, the WNK-SPAK/OSR1-CCC signaling pathway emerges as a new therapeutic target for nervous and non-nervous system disorders. 


\section{Neurological deficits in transgenic mice with modifications of WNK-SPAK/OSR1-CCC signaling pathway}

In the past decade, establishment of specific gene knockout (KO) models or genetic knock-in (KI) mouse models significantly improved our understanding of the physiological function of the WNK-SPAK/OSR1-CCC pathway in the nervous system. Global NKCC1 KO mice exhibited seizure, hearing loss (due to loss of $\mathrm{K}^{-}$secretion in the inner ear and suppressed bumetanide-sensitive ${ }^{86} \mathrm{Rb}$ uptake and chloride fluxes across the secretory epithelium), and slightly diminished blood pressure than wild-type (WT) animals (Table 1) [58]. KCC3 and KCC4 are copiously expressed in both CNS and PNS, and mutations of them can cause various diseases [59]. Two KCC3 KO mouse models have been created for further exploration of the functions of KCC3 [60, 61]. Using homologous recombination truncating mutations to disrupt the SLC12A6 gene of $\mathrm{KCC} 3$ generates $\mathrm{KCC} 3 \mathrm{KO}$ mice (SLC12 $\mathrm{A6}^{-/}$) [60]. The second $\mathrm{KCC} 3 \mathrm{KO}$ mouse line was created by Boettger et al [61], as well as a spontaneous mutation in the Jackson Lab [62]. KCC3 KO mice $\left(\mathrm{SLC} 12 \mathrm{A6}^{-/}\right)$show discoordination and feebleness in the hind limbs 14 days after birth, as well as axonal swelling in the sciatic nerves, hypomyelination, demyelination, and fiber degeneration (Table 1) [63]. In two independent studies, nerve conduction impairment in $\mathrm{KCC} 3 \mathrm{KO}$ mice arose from the combination of impaired ionic clearance and axonal swelling in the sciatic nerve $[63,64]$. Adult KCC3 KO mice showed reduced exploration of their environment and deafness in behavior tests due to abnormal inner ear cells $[60,61]$. Furthermore, in cerebellar slice preparations (which express abundant $\mathrm{KCC} 3$ ), both $\mathrm{WT}$ and $\mathrm{KCC} 3$-null Purkinje cells exhibit swelling in hypotonic conditions but KCC3-null cells failed to normalize their volume after returning to isotonic conditions, suggesting that $\mathrm{KCC} 3-$ dependent RVD was impaired in KCC3 KO cells [61]. Additionally, the seizure threshold of KCC3-null mice is lower than WT mice, which was detected by the patchclamp technique [61].

Inhibition of the WNK-SPAK-CCC cascade can reduce cellular swelling in ischemic stroke brains by concurrently inhibiting NKCC-mediated ionic influx and stimulating KCC-mediated ion efflux. WNK3 $\mathrm{KO}$ mice show normal weight, behavior, and growth [35, 65]. They exhibited less cytotoxic edema after ischemic stroke in the middle cerebral artery occlusion (MCAO) model [34]. However, both adult WNK3 KO and SPAK KO mice have impaired locomotor function (Table 1) [34]. Compared to their WT counterparts, SPAK KO mice display a higher nociceptive threshold [66]. They also exhibit increased thigmotaxis in the open field chamber and spend significantly longer periods of time in the dark area of the light/dark box, indicating an anxiety-like phenotype [66]. These findings suggest that WNK-SPAK-CCC signal pathway is important in regulating function of the nervous system, which may be through fine tuning of $\mathrm{Cl}^{-}$and cell volume homeostasis.

\section{The $\mathrm{Cl}^{-}$cotransporters and WNK-SPAK signaling pathway in ischemic brain edema and hypersecretion of cerebrospinal fluid (CSF)}

The WNK-SPAK-CCC signaling complex plays a role in regulating cell volume and ionic homeostasis in both the CNS and PNS. Considering the special physiology of the brain and skull, cell volume regulation in the CNS is especially important because slight volume changes can affect normal brain function and cause life-threatening problems [21]. Such as in ischemic stroke, activation of NKCC1 causes brain edema (isosmotic cell swelling via increasing the intracellular concentration of $\mathrm{Na}^{+}$and $\mathrm{Cl}^{-}$) and brain injury [16, 67]. Brain edema can increase intracranial pressure, trigger herniation, or even cause death. In a recent experimental ischemic stroke study, WNK3 KO mice displayed significantly decreased cerebral swelling, axonal demyelination, and infarct volume as well as accelerated neurobehavioral recovery, compared to WT mice [35]. WNK3 KO mice have shown two swelling-associated components of ischemic cerebral edema to be mitigated: endothelial and perivascular cytotoxic edema of astrocytes [26]. These effects likely result from decreased $\mathrm{NKCC} 1$ activity and increased KCC3-mediated cellular $\mathrm{Cl}^{-}$efflux [26].

The neuroprotective phenotypes conferred by WNK3 $\mathrm{KO}$ were associated with a decrease in $\mathrm{NKCC1}$ cell surface expression, reduced phosphorylation at $\mathrm{NKCC1}$ stimulatory sites $\left(\mathrm{Thr}^{203} / \mathrm{Thr}^{207} / \mathrm{Thr}^{212}\right.$ ) and a decrease in stimulatory hyperphosphorylations of the SPAK/OSR1 catalytic T-loop [35]. Compared to WT mice, WNK3 KO and SPAK KO (or SPAK heterozygous) mice showed more than a $50 \%$ reduction in infarct volume and associated cerebral edema after ischemic stroke. Cultured primary neurons and oligodendrocytes showed increased tolerance to in vitro ischemia with genetic inhibition of WNK3 or small interfering RNA knockdown of SPAK/OSR1 [34]. Therefore, WNK-SPAK-NKCC1 complex inhibition has therapeutic potential for treating cerebral edema and ischemic brain injury.

In addition, a new report shows that the activation of SPAK, which stimulates NKCC1 at the choroid plexus epithelium (CPE) apical membrane, mediates the intraventricular hemorrhage (IVH)-induced hypersecretion of CSF in a rat model of post-hemorrhagic hydrocephalus (PHH) [68]. Genetic depletion of SPAK normalizes hyperactive CSF secretion rates and reduces $\mathrm{PHH}$ 
symptoms [68]. These findings suggest that pharmacological targeting WNK-SPAK-CCCs signaling pathway presents a novel strategy to treat patients with hydrocephalus instead of invasive CSF shunting.

\section{The $\mathrm{Cl}^{-}$cotransporters and WNK-SPAK signaling pathway in other nervous system diseases}

In humans, mutations of KCC 3 can cause Andermann syndrome, a Mendelian disease characterized by agenesis of the corpus callosum with peripheral neuropathy (ACCPN) [60]. T991A mutations of KCC3 in patient cells stop Thr (991) phosphorylation and cause constitutive KCC3 activity, which interferes with cell volume regulation [55]. Mice with $\mathrm{KCC} 3^{\mathrm{T} 991 \mathrm{~A} / \mathrm{T} 991 \mathrm{~A}}$ mutations displayed constitutive $\mathrm{KCC} 3$ activity and recapitulated aspects of the electrophysiological, histopathological, and clinical findings of peripheral neuropathy patients [55]. On the other hand, the "loss of function mutations" in KCC 3 transporters, mostly due to premature termination, cause hereditary motor and sensory neuropathy (HMSN) with agenesis of the corpus callosum (ACC) [69]. The disorder is characterized by an early onset sensorimotor neuropathy associated with variable degrees of ACC. Individuals are affected at the rate of 1:2117 live births (in the regions of Charlevoix and Saguenay-Lac-Saint-Jean) and carry two copies of a mutant allele which causes KCC3 truncation (Table 1) and loss of transport activity [60]. There are two kinds of gene mutations of T991A and pT813X. KCC3 KO mouse models recapitulate the neuropathy phenotype of the patients $[60,61]$. KCCs also play an important role in the maintenance of nervous system function. Epilepsy is a common CNS disease, and the patients with "loss of function mutations" of KCC3 exhibit a lower seizure threshold, which was also observed in KCC3 KO mice [61]. The complex pathophysiology phenotypes in the nervous system resulting from loss-of-function or gain-of-function of KCC3 present challenges for developing therapeutic treatment by targeting KCC3. However, it is still unclear how $\mathrm{KCC} 3$ is involved in these diseases. Moreover, the time point when $\mathrm{KCC} 3$ function is critical during development or lifetime is still unclear. Therapeutic approaches specifically targeting $\mathrm{KCC} 3$ can be difficult due to a list of unknown cell types that could be potentially affected by KCC3 disruption [70, 71]. Therapies targeting KCC 3 is also likely to affect the other $\mathrm{KCC}$ isoforms due to the high level of conservation in $\mathrm{KCC} 3$ among all isoforms [55, 71]. Improved gene therapy is needed for more specific targeting at KCC3 without disrupting the other isoforms.

Additional reports show that WNK gene families are involved in other neurological diseases. A small number of patients with autism revealed deletions of the WNK3 and FAM120C genes, for which a definitive phenotype has not been previously characterized [72]. Additionally, a genetic disease known as hereditary sensory neuropathy (HSN) or hereditary sensory and autonomic neuropathy (HSAN) was initially believed to be caused by a mutation in a single exon open reading frame (ORF) located within intron 8 of the WNK1 allele, termed "HSN2" [73]. HSN2 was later found to be a nervous system-specific alternately spliced exon of WNK1 as early as 2008 [74]. HSANII affects the peripheral and spinal nerves and results in loss of touch, temperature, and pain sensation [75]. WNK1/HSN2 contributed to a maladaptive decrease in the activity of the KCC2 by increasing its inhibitory phosphorylation at $\mathrm{Thr}^{906 /} \mathrm{Thr}^{1007}$, resulting in an associated loss of GABA-mediated inhibition of chronic pain hypersensitivity after nerve injury [75]. It was found that both genetic knockout and pharmacologic inhibition of WNK/HSN2 leads to amelioration of neuropathic pain while not producing neurological deficits [75]. These findings reveal therapeutic potentials of targeting WNK1 and $\mathrm{KCC} 2$ for neuropathic pain after nerve injury [75]. However, KCC2 KO mice died immediately after birth due to severe motor deficits that prevented respiration [76].

\section{Conclusions}

For decades, cell volume regulation has been a subject undergoing intense study. The WNK-SPAK/OSR1 kinase complex and $\mathrm{Cl}^{-}$cotransporters play a crucial role in regulating cell volume in the nervous system (Fig. 2). Identification of specific human gene mutations in the WNK-SPAK-CCC signaling pathways and development of genetic mouse models enhanced our understanding of the significance of cell volume homeostasis in nervous system disease development and treatment. Oxidative stress directly activates SPAK/OSR1, which can in turn regulates WNK activity, thus indirectly activates WNK (Fig. 2) [30]. Injuries such as peripheral nerve injury, spinal cord injury, and ischemic stroke are also shown to trigger WNK activation (Fig. 2). However, no evidence yet directly links inflammation to WNK activation. Gene mutations in WNK1 and WNK4 lead to compromised cell volume homeostasis and cause PHAII [77], the phenotypic inverse of the salt-wasting Gitelman syndrome (Fig. 2). Other genetic mutations in the ubiquitin E3 ligase components cullin 3 (CUL3) and kelch-like 3 (KLHL3), the upstream genes encoding negative regulators of $\mathrm{WNK}$, increases $\mathrm{WNK}$ abundance [77-79], HSN2 gene mutations lead to a loss-of-function on WNK1 activity and lower the pain threshold through KCC2-mediated GABA hyperpolarization [75]. Therefore, blocking WNK-SPAK/OSR1 may provide a potent means of synchronously inhibiting of NKCC1- 
mediated $\mathrm{Cl}^{-}$influx and enhancing $\mathrm{KCC}$-mediated $\mathrm{Cl}^{-}$ extrusion for multiple syndromes exhibiting depolarized GABA responses and altered $\mathrm{Cl}^{-}$homeostasis, cerebral edema, or hydrocephalus. Mutations of WNK-SPAKCCC complex identify them as therapeutic targets for other nervous system or non-nervous system disorders.

\section{Acknowledgments}

This work is in part supported by NIH R01NS38118 (DS).

\section{Competing interests}

The authors declare that they have no competing interests.

\section{References}

[1] Arroyo JP, Kahle KT, Gamba G (2013). The SLC12 family of electroneutral cation-coupled chloride cotransporters. Mol Aspects Med, 34:288-298.

[2] Moriguchi T, Urushiyama S, Hisamoto N, Iemura S, Uchida S, Natsume T, et al. (2005). WNK1 regulates phosphorylation of cation-chloride-coupled cotransporters via the STE20-related kinases, SPAK and OSR1. J Biol Chem, 280:42685-42693.

[3] Vitari AC, Deak M, Morrice NA, Alessi DR (2005). The WNK1 and WNK4 protein kinases that are mutated in Gordon's hypertension syndrome phosphorylate and activate SPAK and OSR1 protein kinases. Biochem J, 391:17-24.

[4] Richardson C, Alessi DR (2008). The regulation of salt transport and blood pressure by the WNKSPAK/OSR1 signalling pathway. J Cell Sci, 121:32933304.

[5] Shekarabi M, Zhang J, Khanna AR, Ellison DH, Delpire E, Kahle KT (2017). WNK Kinase Signaling in Ion Homeostasis and Human Disease. Cell Metab, 25:285-299.

[6] Piala AT, Moon TM, Akella R, He H, Cobb MH, Goldsmith EJ (2014). Chloride sensing by WNK1 involves inhibition of autophosphorylation. Sci Signal, 7:ra41.

[7] Maruyama J, Kobayashi Y, Umeda T, Vandewalle A, Takeda K, Ichijo H, et al. (2016). Osmotic stress induces the phosphorylation of WNK4 Ser575 via the p38MAPK-MK pathway. Sci Rep, 6:18710.

[8] de Los Heros P, Alessi DR, Gourlay R, Campbell DG, Deak M, Macartney TJ, et al. (2014). The WNKregulated SPAK/OSR1 kinases directly phosphorylate and inhibit the $\mathrm{K}+-\mathrm{Cl}-$ co-transporters. Biochem J, 458:559-573.

[9] Choe KP, Strange K (2007). Evolutionarily conserved WNK and Ste20 kinases are essential for acute volume recovery and survival after hypertonic shrinkage in Caenorhabditis elegans. Am J Physiol Cell Physiol, 293:C915-927.

[10] Simon DB, Nelson-Williams C, Bia MJ, Ellison D, Karet FE, Molina AM, et al. (1996). Gitelman's variant of Bartter's syndrome, inherited hypokalaemic alkalosis, is caused by mutations in the thiazidesensitive Na-Cl cotransporter. Nat Genet, 12:24-30. Naesens M, Steels P, Verberckmoes R, Vanrenterghem Y, Kuypers D (2004). Bartter's and Gitelman's syndromes: from gene to clinic. Nephron Physiol, 96:p65-78.

Yang SS, Lo YF, Wu CC, Lin SW, Yeh CJ, Chu P, et al. (2010). SPAK-knockout mice manifest Gitelman syndrome and impaired vasoconstriction. J Am Soc Nephrol, 21:1868-1877.

[13] Seyberth HW, Schlingmann KP (2011). Bartter- and Gitelman-like syndromes: salt-losing tubulopathies with loop or DCT defects. Pediatr Nephrol, 26:17891802.

[14] Mercado A, Broumand V, Zandi-Nejad K, Enck AH, Mount DB (2006). A C-terminal domain in KCC2 confers constitutive $\mathrm{K}+-\mathrm{Cl}$ - cotransport. J Biol Chem, 281:1016-1026.

[15] Hasbargen T, Ahmed MM, Miranpuri G, Li L, Kahle KT, Resnick D, et al. (2010). Role of NKCC1 and $\mathrm{KCC} 2$ in the development of chronic neuropathic pain following spinal cord injury. Ann N Y Acad Sci, 1198:168-172.

[16] Bhuiyan MIH, Song S, Yuan H, Begum G, Kofler J, Kahle KT, et al. (2017). WNK-Cab39-NKCC1 signaling increases the susceptibility to ischemic brain damage in hypertensive rats. J Cereb Blood Flow Metab, 37:2780-2794.

[17] Dzhala VI, Talos DM, Sdrulla DA, Brumback AC, Mathews GC, Benke TA, et al. (2005). NKCC1 transporter facilitates seizures in the developing brain. Nat Med, 11:1205-1213.

[18] Kaila K, Price TJ, Payne JA, Puskarjov M, Voipio J (2014). Cation-chloride cotransporters in neuronal development, plasticity and disease. Nat Rev Neurosci, 15:637-654.

[19] Kahle KT, Staley KJ, Nahed BV, Gamba G, Hebert SC, Lifton RP, et al. (2008). Roles of the cation-chloride cotransporters in neurological disease. Nat Clin Pract Neurol, 4:490-503.

[20] Pasantes-Morales H, Cardin V, Tuz K (2000). Signaling events during swelling and regulatory volume decrease. Neurochem Res, 25:1301-1314.

[21] McManus ML, Churchwell KB, Strange K (1995). Regulation of cell volume in health and disease. N Engl J Med, 333:1260-1266.

[22] Hoffmann EK, Lambert IH, Pedersen SF (2009). Physiology of cell volume regulation in vertebrates. Physiol Rev, 89:193-277.

[23] Pedersen SF, O'Donnell ME, Anderson SE, Cala PM (2006). Physiology and pathophysiology of $\mathrm{Na}+/ \mathrm{H}+$ exchange and $\mathrm{Na}+-\mathrm{K}+-2 \mathrm{Cl}-$ cotransport in the heart, brain, and blood. Am J Physiol Regul Integr Comp Physiol, 291:R1-25.

[24] Simard JM, Kent TA, Chen M, Tarasov KV, Gerzanich $\mathrm{V}$ (2007). Brain oedema in focal ischaemia: molecular pathophysiology and theoretical implications. Lancet Neurol, 6:258-268.

[25] McCormick JA, Ellison DH (2011). The WNKs: 
atypical protein kinases with pleiotropic actions. Physiol Rev, 91:177-219.

[26] Zhang J, Gao G, Begum G, Wang J, Khanna AR, Shmukler BE, et al. (2016). Functional kinomics establishes a critical node of volume-sensitive cation$\mathrm{Cl}(-)$ cotransporter regulation in the mammalian brain. Sci Rep, 6:35986.

[27] Rinehart J, Maksimova YD, Tanis JE, Stone KL, Hodson CA, Zhang J, et al. (2009). Sites of regulated phosphorylation that control $\mathrm{K}-\mathrm{Cl}$ cotransporter activity. Cell, 138:525-536.

[28] Adragna NC, Ravilla NB, Lauf PK, Begum G, Khanna AR, Sun D, et al. (2015). Regulated phosphorylation of the $\mathrm{K}-\mathrm{Cl}$ cotransporter $\mathrm{KCC} 3$ is a molecular switch of intracellular potassium content and cell volume homeostasis. Front Cell Neurosci, 9:255.

[29] Jennings ML, Schulz RK (1991). Okadaic acid inhibition of $\mathrm{KCl}$ cotransport. Evidence that protein dephosphorylation is necessary for activation of transport by either cell swelling or N-ethylmaleimide. J Gen Physiol, 97:799-817.

[30] Thastrup JO, Rafiqi FH, Vitari AC, Pozo-Guisado E, Deak M, Mehellou Y, et al. (2012). SPAK/OSR1 regulate $\mathrm{NKCC} 1$ and $\mathrm{WNK}$ activity: analysis of WNK isoform interactions and activation by T-loop transautophosphorylation. Biochem J, 441:325-337.

[31] Markkanen M, Ludwig A, Khirug S, Pryazhnikov E, Soni S, Khiroug L, et al. (2017). Implications of the $\mathrm{N}$-terminal heterogeneity for the neuronal $\mathrm{K}-\mathrm{Cl}$ cotransporter KCC2 function. Brain Res, 1675:87-101.

[32] Vitari AC, Thastrup J, Rafiqi FH, Deak M, Morrice NA, Karlsson HK, et al. (2006). Functional interactions of the SPAK/OSR1 kinases with their upstream activator WNK1 and downstream substrate NKCC1. Biochem J, 397:223-231.

[33] Alessi DR, Zhang J, Khanna A, Hochdorfer T, Shang Y, Kahle KT (2014). The WNK-SPAK/OSR1 pathway: master regulator of cation-chloride cotransporters. Sci Signal, 7:re3.

[34] Zhao H, Nepomuceno R, Gao X, Foley LM, Wang S, Begum G, et al. (2017). Deletion of the WNK3-SPAK kinase complex in mice improves radiographic and clinical outcomes in malignant cerebral edema after ischemic stroke. J Cereb Blood Flow Metab, 37:550563.

[35] Begum G, Yuan H, Kahle KT, Li L, Wang S, Shi Y, et al. (2015). Inhibition of WNK3 Kinase Signaling Reduces Brain Damage and Accelerates Neurological Recovery After Stroke. Stroke, 46:1956-1965.

[36] Pasantes-Morales H, Tuz K (2006). Volume changes in neurons: hyperexcitability and neuronal death. Contrib Nephrol, 152:221-240.

[37] Terker AS, Zhang C, Erspamer KJ, Gamba G, Yang CL, Ellison DH (2016). Unique chloride-sensing properties of WNK4 permit the distal nephron to modulate potassium homeostasis. Kidney Int, 89:127134.

[38] Gagnon KB, England R, Delpire E (2006). Characterization of SPAK and OSR1, regulatory kinases of the Na-K-2Cl cotransporter. Mol Cell Biol,
26:689-698

[39] Herbison AE, Moenter SM (2011). Depolarising and hyperpolarising actions of $\mathrm{GABA}(\mathrm{A})$ receptor activation on gonadotrophin-releasing hormone neurones: towards an emerging consensus. J Neuroendocrinol, 23:557-569.

[40] Kahle KT, Delpire E (2016). Kinase-KCC2 coupling: Cl- rheostasis, disease susceptibility, therapeutic target. J Neurophysiol, 115:8-18.

[41] Ivakine EA, Acton BA, Mahadevan V, Ormond J, Tang M, Pressey JC, et al. (2013). Neto2 is a KCC2 interacting protein required for neuronal $\mathrm{Cl}$ - regulation in hippocampal neurons. Proc Natl Acad Sci U S A, 110:3561-3566.

[42] Heubl M, Zhang J, Pressey JC, Al Awabdh S, Renner M, Gomez-Castro F, et al. (2017). GABAA receptor dependent synaptic inhibition rapidly tunes KCC2 activity via the $\mathrm{Cl}(-)$-sensitive WNK1 kinase. Nat Commun, 8:1776.

[43] Ge S, Goh EL, Sailor KA, Kitabatake Y, Ming GL, Song H (2006). GABA regulates synaptic integration of newly generated neurons in the adult brain. Nature, 439:589-593.

[44] Spitzer NC (2010). How GABA generates depolarization. J Physiol, 588:757-758.

[45] Cellot G, Cherubini E (2014). GABAergic signaling as therapeutic target for autism spectrum disorders. Front Pediatr, 2:70.

[46] Arion D, Lewis DA (2011). Altered expression of regulators of the cortical chloride transporters NKCC1 and KCC2 in schizophrenia. Arch Gen Psychiatry, 68:21-31.

[47] Tornberg J, Voikar V, Savilahti H, Rauvala H, Airaksinen MS (2005). Behavioural phenotypes of hypomorphic KCC2-deficient mice. Eur J Neurosci, 21:1327-1337.

[48] Khanna A, Walcott BP, Kahle KT (2013). Limitations of Current GABA Agonists in Neonatal Seizures: Toward GABA Modulation Via the Targeting of Neuronal Cl(-) Transport. Front Neurol, 4:78.

[49] Boulenguez P, Liabeuf S, Bos R, Bras H, Jean-Xavier C, Brocard C, et al. (2010). Down-regulation of the potassium-chloride cotransporter KCC2 contributes to spasticity after spinal cord injury. Nat Med, 16:302307.

[50] Rangroo Thrane V, Thrane AS, Wang F, Cotrina ML, Smith NA, Chen M, et al. (2013). Ammonia triggers neuronal disinhibition and seizures by impairing astrocyte potassium buffering. Nat Med, 19:16431648.

[51] Coull JA, Beggs S, Boudreau D, Boivin D, Tsuda M, Inoue $\mathrm{K}$, et al. (2005). BDNF from microglia causes the shift in neuronal anion gradient underlying neuropathic pain. Nature, 438:1017-1021.

[52] Kahle KT, Khanna A, Clapham DE, Woolf CJ (2014). Therapeutic restoration of spinal inhibition via druggable enhancement of potassium-chloride cotransporter KCC2-mediated chloride extrusion in peripheral neuropathic pain. JAMA Neurol, 71:640645. 
[53] Sanchez-Brualla I, Boulenguez P, Brocard C, Liabeuf S, Viallat-Lieutaud A, Navarro X, et al. (2018). Activation of 5-HT2A Receptors Restores KCC2 Function and Reduces Neuropathic Pain after Spinal Cord Injury. Neuroscience, 387:48-57.

[54] Alvarez-Leefmans FJ, Gamino SM, Giraldez F, Nogueron I (1988). Intracellular chloride regulation in amphibian dorsal root ganglion neurones studied with ion-selective microelectrodes. J Physiol, 406:225-246.

[55] Kahle KT, Flores B, Bharucha-Goebel D, Zhang J, Donkervoort S, Hegde M, et al. (2016). Peripheral motor neuropathy is associated with defective kinase regulation of the KCC3 cotransporter. Sci Signal, 9:ra77.

[56] Andrew RD, Labron MW, Boehnke SE, Carnduff L, Kirov SA (2007). Physiological evidence that pyramidal neurons lack functional water channels. Cereb Cortex, 17:787-802.

[57] Payne JA, Stevenson TJ, Donaldson LF (1996). Molecular characterization of a putative $\mathrm{K}-\mathrm{Cl}$ cotransporter in rat brain. A neuronal-specific isoform. J Biol Chem, 271:16245-16252.

[58] Dixon MJ, Gazzard J, Chaudhry SS, Sampson N, Schulte BA, Steel KP (1999). Mutation of the Na-K$\mathrm{Cl}$ co-transporter gene Slc12a2 results in deafness in mice. Hum Mol Genet, 8:1579-1584.

[59] Adragna NC, Di Fulvio M, Lauf PK (2004). Regulation of $\mathrm{K}-\mathrm{Cl}$ cotransport: from function to genes. J Membr Biol, 201:109-137.

[60] Howard HC, Mount DB, Rochefort D, Byun N, Dupre $\mathrm{N}$, Lu J, et al. (2002). The $\mathrm{K}-\mathrm{Cl}$ cotransporter $\mathrm{KCC} 3$ is mutant in a severe peripheral neuropathy associated with agenesis of the corpus callosum. Nat Genet, 32:384-392.

[61] Boettger T, Rust MB, Maier H, Seidenbecher T, Schweizer M, Keating DJ, et al. (2003). Loss of K-Cl co-transporter KCC3 causes deafness, neurodegeneration and reduced seizure threshold. Embo j, 22:5422-5434.

[62] Jiao Y, Jin X, Yan J, Zhang C, Jiao F, Li X, et al. (2008). A deletion mutation in Slc12a6 is associated with neuromuscular disease in gaxp mice. Genomics, 91:407-414.

[63] Byun N, Delpire E (2007). Axonal and periaxonal swelling precede peripheral neurodegeneration in KCC3 knockout mice. Neurobiol Dis, 28:39-51.

[64] Sun YT, Lin TS, Tzeng SF, Delpire E, Shen MR (2010). Deficiency of electroneutral $\mathrm{K}+-\mathrm{Cl}$ - cotransporter 3 causes a disruption in impulse propagation along peripheral nerves. Glia, 58:1544-1552.

[65] Oi K, Sohara E, Rai T, Misawa M, Chiga M, Alessi $\mathrm{DR}$, et al. (2012). A minor role of WNK3 in regulating phosphorylation of renal NKCC2 and NCC cotransporters in vivo. Biol Open, 1:120-127.

[66] Geng Y, Byun N, Delpire E (2010). Behavioral analysis of Ste20 kinase SPAK knockout mice. Behav Brain Res, 208:377-382.

[67] Brillault J, Lam TI, Rutkowsky JM, Foroutan S, O'Donnell ME (2008). Hypoxia effects on cell volume and ion uptake of cerebral microvascular endothelial cells. Am J Physiol Cell Physiol, 294:C88-96.

[68] Karimy JK, Zhang J, Kurland DB, Theriault BC, Duran D, Stokum JA, et al. (2017). Inflammationdependent cerebrospinal fluid hypersecretion by the choroid plexus epithelium in posthemorrhagic hydrocephalus. Nat Med, 23:997-1003.

[69] Delpire E, Kahle KT (2017). The KCC3 cotransporter as a therapeutic target for peripheral neuropathy. Expert Opin Ther Targets, 21:113-116.

[70] Shekarabi M, Moldrich RX, Rasheed S, SalinCantegrel A, Laganiere J, Rochefort D, et al. (2012). Loss of neuronal potassium/chloride cotransporter 3 (KCC3) is responsible for the degenerative phenotype in a conditional mouse model of hereditary motor and sensory neuropathy associated with agenesis of the corpus callosum. J Neurosci, 32:3865-3876.

[71] Flores B, Schornak CC, Delpire E (2018). A role for $\mathrm{KCC} 3$ in maintaining cell volume of peripheral nerve fibers. Neurochem Int.

[72] Qiao Y, Liu X, Harvard C, Hildebrand MJ, RajcanSeparovic E, Holden JJ, et al. (2008). Autismassociated familial microdeletion of Xp11.22. Clin Genet, 74:134-144.

[73] Lafreniere RG, MacDonald ML, Dube MP, MacFarlane J, O'Driscoll M, Brais B, et al. (2004). Identification of a novel gene (HSN2) causing hereditary sensory and autonomic neuropathy type II through the Study of Canadian Genetic Isolates. Am J Hum Genet, 74:1064-1073.

[74] Shekarabi M, Girard N, Riviere JB, Dion P, Houle M, Toulouse A, et al. (2008). Mutations in the nervous system--specific HSN2 exon of WNK1 cause hereditary sensory neuropathy type II. J Clin Invest, 118:2496-2505.

[75] Kahle KT, Schmouth JF, Lavastre V, Latremoliere A, Zhang J, Andrews N, et al. (2016). Inhibition of the kinase WNK1/HSN2 ameliorates neuropathic pain by restoring GABA inhibition. Sci Signal, 9:ra32.

[76] Hubner CA, Stein V, Hermans-Borgmeyer I, Meyer T, Ballanyi K, Jentsch TJ (2001). Disruption of KCC2 reveals an essential role of $\mathrm{K}-\mathrm{Cl}$ cotransport already in early synaptic inhibition. Neuron, 30:515-524.

[77] Ohta A, Schumacher FR, Mehellou Y, Johnson C, Knebel A, Macartney TJ, et al. (2013). The CUL3KLHL3 E3 ligase complex mutated in Gordon's hypertension syndrome interacts with and ubiquitylates WNK isoforms: disease-causing mutations in KLHL3 and WNK4 disrupt interaction. Biochem J, 451:111-122.

[78] Shibata S, Zhang J, Puthumana J, Stone KL, Lifton RP (2013). Kelch-like 3 and Cullin 3 regulate electrolyte homeostasis via ubiquitination and degradation of WNK4. Proc Natl Acad Sci U S A, 110:7838-7843.

[79] Wakabayashi M, Mori T, Isobe K, Sohara E, Susa K, Araki Y, et al. (2013). Impaired KLHL3-mediated ubiquitination of WNK4 causes human hypertension. Cell Rep, 3:858-868.

[80] Adachi M, Asakura Y, Sato Y, Tajima T, Nakajima T, Yamamoto T, et al. (2007). Novel SLC12A1 (NKCC2) mutations in two families with Bartter syndrome type 
1. Endocr J, 54:1003-1007.

[81] Konopacka A, Qiu J, Yao ST, Greenwood MP, Greenwood M, Lancaster T, et al. (2015). Osmoregulation requires brain expression of the renal $\mathrm{Na}-\mathrm{K}-2 \mathrm{Cl}$ cotransporter NKCC2. J Neurosci, 35:5144-5155.

[82] Takahashi N, Chernavvsky DR, Gomez RA, Igarashi P, Gitelman HJ, Smithies O (2000). Uncompensated polyuria in a mouse model of Bartter's syndrome. Proc Natl Acad Sci U S A, 97:5434-5439.

[83] Nezu A, Parvin MN, Turner RJ (2009). A conserved hydrophobic tetrad near the $\mathrm{C}$ terminus of the secretory $\mathrm{Na}+\mathrm{K}+-2 \mathrm{Cl}$ - cotransporter $(\mathrm{NKCC} 1)$ is required for its correct intracellular processing. J Biol Chem, 284:6869-6876.

[84] Orlov SN, Koltsova SV, Kapilevich LV, Gusakova SV, Dulin NO (2015). NKCC1 and NKCC2: The pathogenetic role of cation-chloride cotransporters in hypertension. Genes Dis, 2:186-196.

[85] Nejsum LN, Praetorius J, Nielsen S (2005). NKCC1 and NHE1 are abundantly expressed in the basolateral plasma membrane of secretory coil cells in rat, mouse, and human sweat glands. Am J Physiol Cell Physiol, 289:C333-340.

[86] Delpire E, Lu J, England R, Dull C, Thorne T (1999). Deafness and imbalance associated with inactivation of the secretory Na-K-2Cl co-transporter. Nat Genet, 22:192-195.

[87] Nicolet-Barousse L, Blanchard A, Roux C, Pietri L, Bloch-Faure M, Kolta S, et al. (2005). Inactivation of the $\mathrm{Na}-\mathrm{Cl}$ co-transporter (NCC) gene is associated with high BMD through both renal and bone mechanisms: analysis of patients with Gitelman syndrome and Ncc null mice. J Bone Miner Res, 20:799-808.

[88] Yang SS, Lo YF, Yu IS, Lin SW, Chang TH, Hsu YJ, et al. (2010). Generation and analysis of the thiazidesensitive $\mathrm{Na}+$-Cl- cotransporter (Ncc/Slc12a3) Ser707X knockin mouse as a model of Gitelman syndrome. Hum Mutat, 31:1304-1315.

[89] Schultheis PJ, Lorenz JN, Meneton P, Nieman ML, Riddle TM, Flagella M, et al. (1998). Phenotype resembling Gitelman's syndrome in mice lacking the apical $\mathrm{Na}+-\mathrm{Cl}$ - cotransporter of the distal convoluted tubule. J Biol Chem, 273:29150-29155.

[90] Rust MB, Alper SL, Rudhard Y, Shmukler BE, Vicente $\mathrm{R}$, Brugnara C, et al. (2007). Disruption of erythroid $\mathrm{K}-\mathrm{Cl}$ cotransporters alters erythrocyte volume and partially rescues erythrocyte dehydration in SAD mice. J Clin Invest, 117:1708-1717.

[91] Blaesse P, Airaksinen MS, Rivera C, Kaila K (2009). Cation-chloride cotransporters and neuronal function.
Neuron, 61:820-838.

[92] Delpire E, Mount DB (2002). Human and murine phenotypes associated with defects in cation-chloride cotransport. Annu Rev Physiol, 64:803-843.

[93] Rust MB, Faulhaber J, Budack MK, Pfeffer C, Maritzen T, Didie M, et al. (2006). Neurogenic mechanisms contribute to hypertension in mice with disruption of the $\mathrm{K}-\mathrm{Cl}$ cotransporter KCC3. Circ Res, 98:549-556.

[94] Gamba G (2005). Molecular physiology and pathophysiology of electroneutral cation-chloride cotransporters. Physiol Rev, 85:423-493.

[95] Boettger T, Hubner CA, Maier H, Rust MB, Beck FX, Jentsch TJ (2002). Deafness and renal tubular acidosis in mice lacking the $\mathrm{K}-\mathrm{Cl}$ co-transporter Kcc4. Nature, 416:874-878.

[96] Xie J, Yoon J, Yang SS, Lin SH, Huang CL (2013). WNK1 protein kinase regulates embryonic cardiovascular development through the OSR1 signaling cascade. J Biol Chem, 288:8566-8574.

[97] Lin SH, Yu IS, Jiang ST, Lin SW, Chu P, Chen A, et al. (2011). Impaired phosphorylation of $\mathrm{Na}(+)-\mathrm{K}(+)-$ $2 \mathrm{Cl}(-)$ cotransporter by oxidative stress-responsive kinase-1 deficiency manifests hypotension and Bartter-like syndrome. Proc Natl Acad Sci U S A, 108:17538-17543.

[98] Tu SW, Bugde A, Luby-Phelps K, Cobb MH (2011). WNK1 is required for mitosis and abscission. Proc Natl Acad Sci U S A, 108:1385-1390.

[99] Wilson FH, Disse-Nicodeme S, Choate KA, Ishikawa K, Nelson-Williams C, Desitter I, et al. (2001). Human hypertension caused by mutations in WNK kinases. Science, 293:1107-1112.

[100] Verissimo F, Jordan P (2001). WNK kinases, a novel protein kinase subfamily in multi-cellular organisms. Oncogene, 20:5562-5569.

[101] Hong C, Moorefield KS, Jun P, Aldape KD, Kharbanda S, Phillips HS, et al. (2007). Epigenome scans and cancer genome sequencing converge on WNK2, a kinase-independent suppressor of cell growth. Proc Natl Acad Sci U S A, 104:10974-10979.

[102] Mederle K, Mutig K, Paliege A, Carota I, Bachmann $\mathrm{S}$, Castrop $\mathrm{H}$, et al. (2013). Loss of WNK3 is compensated for by the WNK1/SPAK axis in the kidney of the mouse. Am J Physiol Renal Physiol, 304:F1198-1209.

[103] Terker AS, Castaneda-Bueno M, Ferdaus MZ, Cornelius RJ, Erspamer KJ, Su XT, et al. (2018). With no lysine kinase 4 modulates sodium potassium 2 chloride cotransporter activity in vivo. Am J Physiol Renal Physiol, 315:F781-f790. 